\title{
Changes of Photovoltaic Performance as a Function of Positioning Relative to the Focus Points of a Concentrator PV Module: Case Study
}

\author{
Henrik Zsiborács ${ }^{1}$, Nóra Hegedúsné Baranyai ${ }^{1, *}$, András Vincze ${ }^{2}$, István Háber ${ }^{3}$, \\ Philipp Weihs ${ }^{4}$, Sandro Oswald ${ }^{4}{ }^{\mathbb{D}}$, Christian Gützer $^{4}$ and Gábor Pintér ${ }^{1}$ \\ 1 Department of Economic Methodology, University of Pannonia, Georgikon Faculty, 8360 Keszthely, Hungary \\ 2 Department of Foreign Languages, Georgikon Faculty, University of Pannonia, 8360 Keszthely, Hungary \\ 3 Department of Mechanical Engineering, University of Pécs, Faculty of Engineering and Information \\ Technology, 7624 Pécs, Hungary \\ 4 Department of Water, Atmosphere and Environment, Institute of Meteorology, University of Natural \\ Resources and Life Sciences Vienna, 1180 Vienna, Austria \\ * Correspondence: baranyai@georgikon.hu; Tel.: +36-30-373-8550
}

Received: 15 July 2019; Accepted: 14 August 2019; Published: 17 August 2019

\begin{abstract}
This article examines the positioning features of polycrystalline, monocrystalline, and amorphous silicon modules relative to the focus points of concentrator photovoltaic modules under real meteorological conditions using a dual tracking system. The performance of the photovoltaic modules mounted on a dual-axis tracking system was regarded as a function of module orientation where the modules were moved step by step up to a point where their inclination differed by $30^{\circ}$ compared to the ideal focus point position of the reference concentrator photovoltaic module. The inclination difference relative to the ideal focus point position was determined by the perfect perpendicularity to the rays of the sun. Technology-specific results show the accuracy of a sun tracking photovoltaic system that is required to keep the loss in power yield below a defined level. The loss in power yield, determined as a function of the measurement results, also showed that the performance insensitivity thresholds of the monocrystalline, polycrystalline, and amorphous silicon modules depended on the direction of the alignment changes. The performance deviations showed clear azimuth dependence. Changing the tilt of the modules towards north and south showed little changes in results, but inclination changes towards northwest, southwest, southeast, and northeast produced results diverging more markedly from each other. These results may make the planning of solar tracking sensor investments easier and help with the estimate calculations of the total investment and operational costs and their return concerning monocrystalline, polycrystalline, and amorphous silicon photovoltaic systems. The results also provide guidance for the tracking error values of the solar tracking sensor.
\end{abstract}

Keywords: solar energy; solar module; sun-tracking; sun-tracking sensor; azimuth angle; tilt angle

\section{Introduction}

\subsection{Changes in the Spread of Photovoltaic Technologies in the World}

Nowadays, more and more countries understand the harmful consequences of climate change worldwide. Their common goal should be to keep the global temperature rise below $2{ }^{\circ} \mathrm{C}$ compared to the pre-industrial level and aiming for a maximum increase of only $1.5^{\circ} \mathrm{C}$ [1]. In the transformation needed to achieve these targets and to reduce the greenhouse effect, the use of renewable energy plays a key role. Advances in renewable energy technologies have provided several sustainable alternatives, 
and more and more attention is also paid to solar energy. Many cities around the world have started to develop their solar energy programs in their urban planning to promote sustainable development and environmental protection. Energy from the Sun, which is available for all mankind, is the basis of most natural processes and it is a sustainable, plentiful, and clean resource [2-11]. The annual solar energy potential arriving on the Earth's surface is approximately 8000 times greater than the current energy demand of the world. Photovoltaic (PV) technologies use PV cells and modules which transform the incoming solar energy into DC energy [12-14].

In the PV sector a significant market increase has been observed in the last 10 years mainly due to the state subsidies introduced in many countries, the falling investment costs and the accelerated technological development $[6,15,16]$. In 2018 the share of renewable electricity production was $26.2 \%$ of all the electricity produced worldwide, of which PV technology represented $2.4 \%$. In 2018 the global built-in photovoltaic capacity was $505 \mathrm{GW}$, with the largest proportions being China's $177.5 \mathrm{GW}$, the European Union's 115 GW, the USA's 62.4 GW and Japan's 56 GW (Figure 1) [6,17,18].

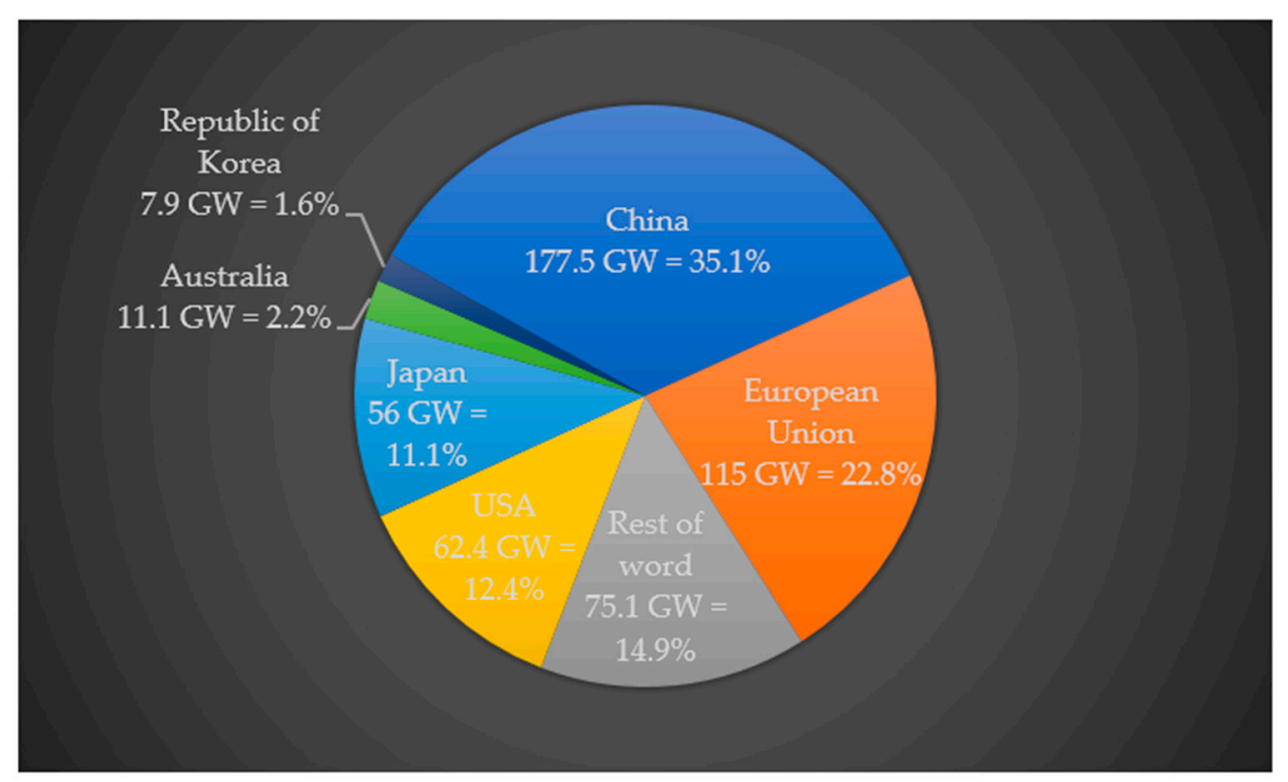

Figure 1. Estimated global solar photovoltaic capacity, by country and region in 2018, based on [18].

The amount of electric energy produced by PV systems depends primarily on the solar radiation, the temperature, the technology, the current natural factors, the composition of the particular module and the combined effects of the installation and the efficiency rates. PV systems are primarily mounted on fixed mounting systems for economic reasons. However, an advanced mounting technique is to use a solar tracking system to increase the energy production [19-22].

\subsection{Energy Production and Accuracy Features of Dual Tracking PV Systems}

With the help of a solar tracking system, the orbit of the Sun can be monitored with sensors. An ideal solar tracker allows PV panels or complete systems to precisely follow the sun within an accuracy of less than 0.1 degree. This makes it possible to maximize the current energy production since sun tracking systems keep the PV modules perpendicular to the incoming solar radiation. [19,22,23]. In order to obtain maximum efficiency, three main factors are crucial:

- an optimal configuration of the tracking axes [24,25],

- an optimal configuration of the control systems [26],

- $\quad$ the optimization of the moving fixtures [27].

Currently, there are two different classes of solar tracking systems, whose characteristics have been examined by many manuscripts (Figure 2): 
- $\quad$ solar tracking systems with one axis (rotating around one axis) [28-32],

- $\quad$ solar tracking systems with two axes (rotating around two axes) [22,33-35].

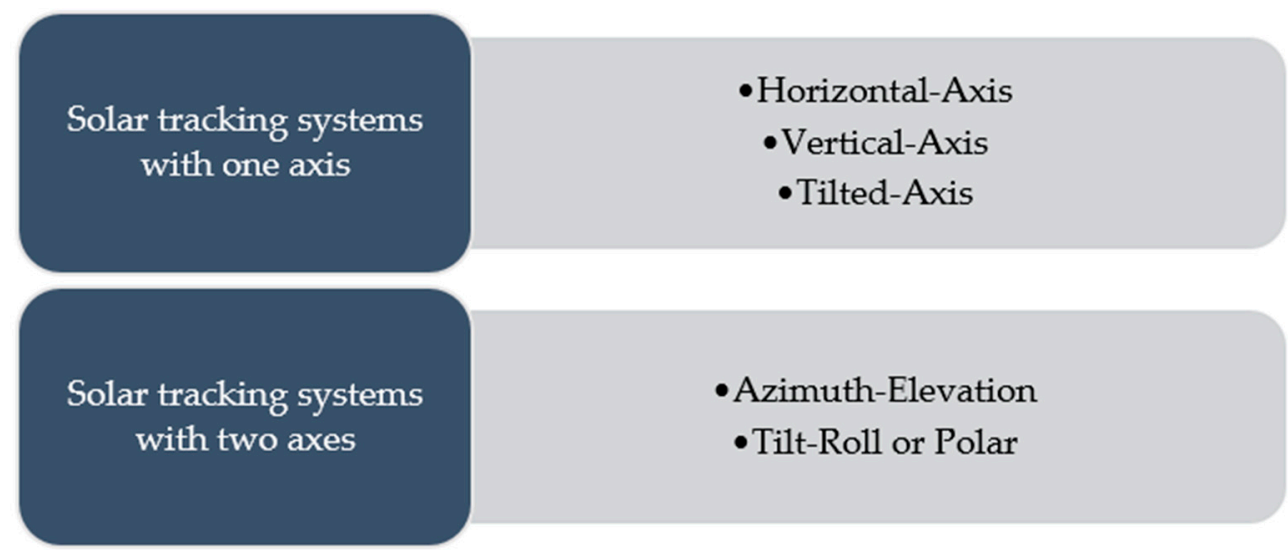

Figure 2. Types of sun tracker solutions based on [36].

The efficiency of a solar tracking solution will be higher than that of a fixed PV system. Single- and dual-axis solar tracking PV systems can easily increase their energy produced by $12-42 \%$, depending on the installation site and mounting type [22,25,37-39]. Focusing on Europe, Vokas et al. (2015) collected many ( $>100$ pieces) real, detailed energy production measurement data from single- and dual-axis PV plants all over Greece. They investigated the real (measured) data comparison between dual-axis and fix-mounted PV systems in 8 towns in Greece (Kilkis, Ilia, Serres, Trikala, Evros, Karditsa, Magnisisa, and Rodope). It can be stated that the percentage of the average difference between the average performances of dual-axis and fix-mounted PV systems was 34.8\%. Results delivered by other similar researches in other geographic locations (Canada, Turkey, Spain) were close to the average of the figures obtained in Greece (Table 1) [19].

Several sources suggest that dual-axis tracking solutions are more efficient and can also be cost-effective if bigger systems are implemented. Nevertheless, the implementation of solar tracking devices is only justified if the amount of electrical energy produced compensates for the costs of the equipment, the maintenance and the energy consumed by the moving parts [23,38,40-42].

Regarding solar tracking technologies, the implementation of good tracking and control algorithms is also crucial. These systems are generally classified into open- and closed loop systems depending on the type of control strategy involved and the mode of signal operation. [23,43,44]. An important aspect is the performance and the error of solar tracking systems. Lee et al. (2009) present the performance and error relationship of many precise solar tracking systems and algorithms. It is apparent from the research that there is typically a $0.0003^{\circ}-1^{\circ}$ tracking error tolerance, but nowadays the investment costs of such systems are high [45]. Nevertheless, there are solar tracking systems and sensors which are easily and cheaply available to the public but their tracking error tolerance is at least $1.5^{\circ}$ [46]. According to Nsengiyumva et al. (2018) solar tracking system devices are exceptionally attractive and always yield more than $98.5 \%$ of their full tracking efficiency even when the aim is off by $10^{\circ}$. Notwithstanding, it is necessary to minimize small tracking errors to ensure the maximum energy gain on a long term basis $[23,47]$. An alternative option to control a two-axis PV tracking system without sensors is based on a mathematical sun tracking model for the specified geolocation (Zenith angle calculation). This model was presented in the study by Haber et al., 2013, which could give the perfect position but did not consider the diffuse radiation [48]. 
Table 1. The gain in yearly real energy production compared to optimally positioned south-facing crystalline photovoltaic (PV) systems.

\begin{tabular}{ccr}
\hline Country (City/Town) & $\begin{array}{c}\text { Gain in Yearly Real Energy } \\
\text { Production Achieved by Using } \\
\text { a Double-Axis Tracker System (\%) }\end{array}$ & Reference \\
\hline Turkey (Muğla) & 30.8 & {$[22]$} \\
Canada (Vermilion) & 31 & {$[49]$} \\
Spain (Palencia) & 30.5 & {$[50]$} \\
Greece (average) & 34.5 & \\
Greece (Ilia) & 21 & \\
Greece (Serres) & 27.4 & \\
Greece (Karditsa) & 37.3 & \\
Greece (Evros) & 42.2 & \\
Greece (Kilkis) & 34.5 & \\
Greece (Trikala) & 34.6 & \\
Greece (Magnisia) & 39.1 & \\
Greece (Rodopi) & 42.2 & \\
\hline
\end{tabular}

Due to various technical and economic aspects it is necessary to examine the technology-specific performance losses in the case of inaccurate sun tracking compared to the ideal position. This article tries to find an answer to the question when it is necessary to reposition a sun tracking PV system.

Furthermore, current scientific literature does not give an answer regarding the performance insensitivity thresholds of the most widely used PV technologies (m-Si or p-Si) [51] in the case of inaccurate sun tracking or sensor failures. Another important issue is whether the yield loss resulting from the solar tracking uncertainty shows an azimuthal dependence. These uncertain issues motivated this scientific work.

\section{Material and Methods}

\subsection{Study Location}

The experiment was conducted at the measuring station of the University of Pannonia Georgikon Faculty, Department of Economic Methodology, in Hungary in Keszthely (longitude: 17.26609 , latitude: $46.76750^{\circ}$, altitude $108 \mathrm{~m}$ ) in the summers of 2017, 2018 and 2019 on fourteen different days.

\subsection{System Description}

In the present experiment, a dual-axis tracking system equipped with modules using concentrator photovoltaic (CPV), amorphous silicon (a-Si), polycrystalline (p-Si) and monocrystalline (m-Si) PV technologies was examined under real meteorological conditions at the same measuring point. The CPV module on the monitoring system assisted only with the accurate sun adjustment in this research (Table 2, Figures 3 and 4).

Table 2. Technical information of the PV modules. (standard test conditions: air mass 1.5; cell temperature $25^{\circ} \mathrm{C}$; irradiance $=1000 \mathrm{~W} / \mathrm{m}^{2} / \mathrm{m}$-Si, p-Si, a-Si modules; irradiance $=850 \mathrm{~W} / \mathrm{m}^{2} /$ concentrator photovoltaic (CPV) module).

\begin{tabular}{ccccc}
\hline Module Type & CPV & a-Si & m-Si & p-Si \\
\hline Model & CX-75-III & G-EA050 & SM636-50 & SL50TU-18P \\
\hline Nominal power (Pmax) (W) & 75 & 50 & 50 & 50 \\
Performance tolerance (\%) & $\pm 5 \%$ & $\pm 10 \%$ & $\pm 3 \%$ & $\pm 3 \%$ \\
MPP voltage (Vmp) (V) & 135 & 67 & 18.18 & 19.12 \\
MPP current (Imp) (A) & 0.55 & 0.75 & 2.8 & 2.62 \\
Open circuit voltage (Voc) (V) & 150 & 91.8 & 23.17 & 22.68 \\
Short circuit current (Isc) (A) & 0.64 & 1.19 & 3.08 & 2.80 \\
Efficiency (\%) & 27.2 & 5.3 & 14.4 & 13.7 \\
Temperature Coefficient $\left(\% /{ }^{\circ} \mathrm{C}\right)$ & 0.15 & 0.27 & 0.5 & 0.5 \\
\hline
\end{tabular}




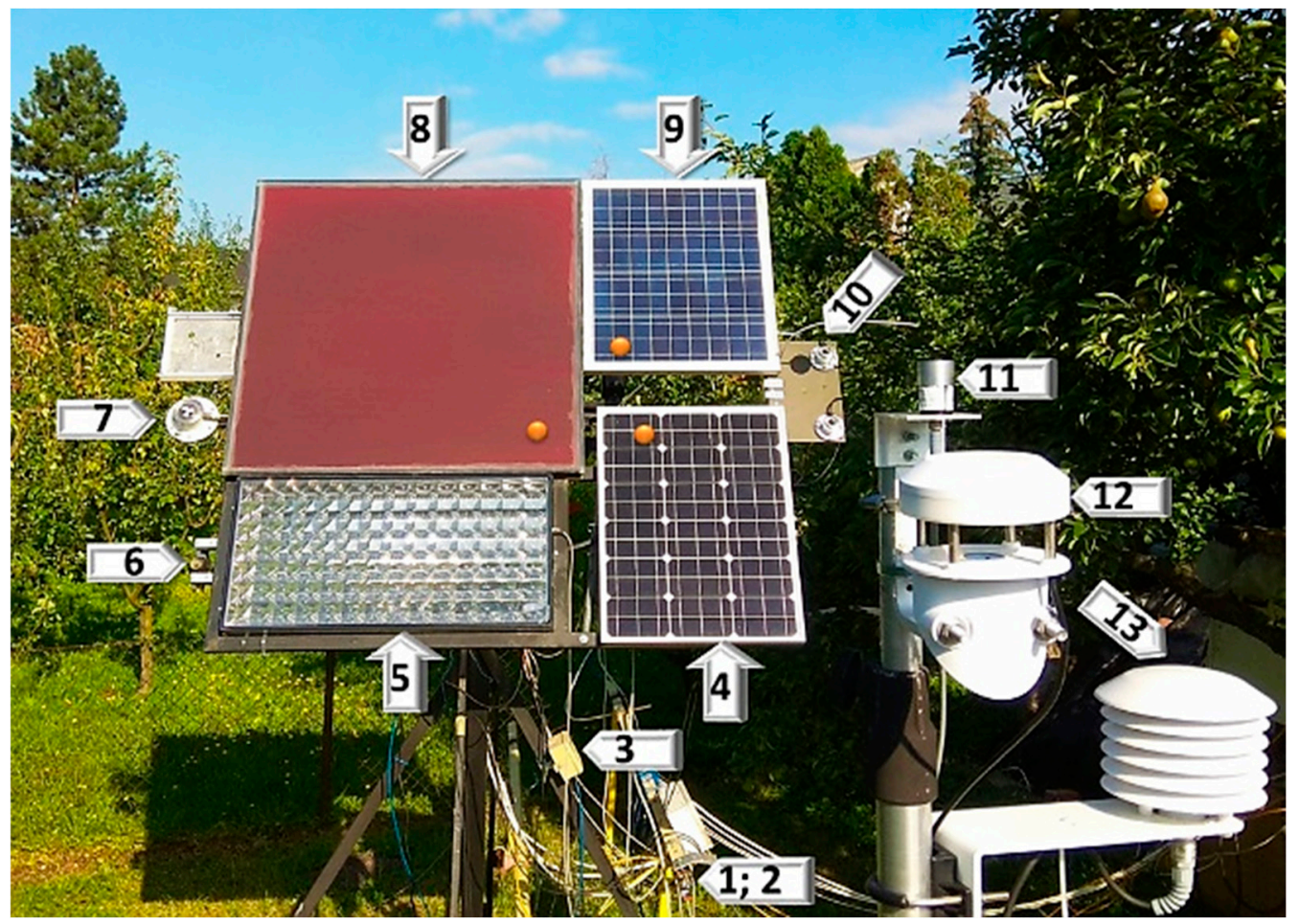

Figure 3. The measuring station in Keszthely (1, HYTE-ANA-1735 humidity module [measuring air humidity]; 2, Pt 100 sensor; 3, manual/automatic tracking control unit; 4, m-Si module; 5, CPV module; 6, photosensors; 7, Eppley Black and White pyranometer; 8, a-Si module; 9, p-Si module; 10, Hukseflux LP02 pyranometers; 11, EMS 11 Silicon PV detector; 12, DS-2 Sonic anemometer; 13, OTT TRH relative humidity sensor; Orange dot: Pt 100 sensors).

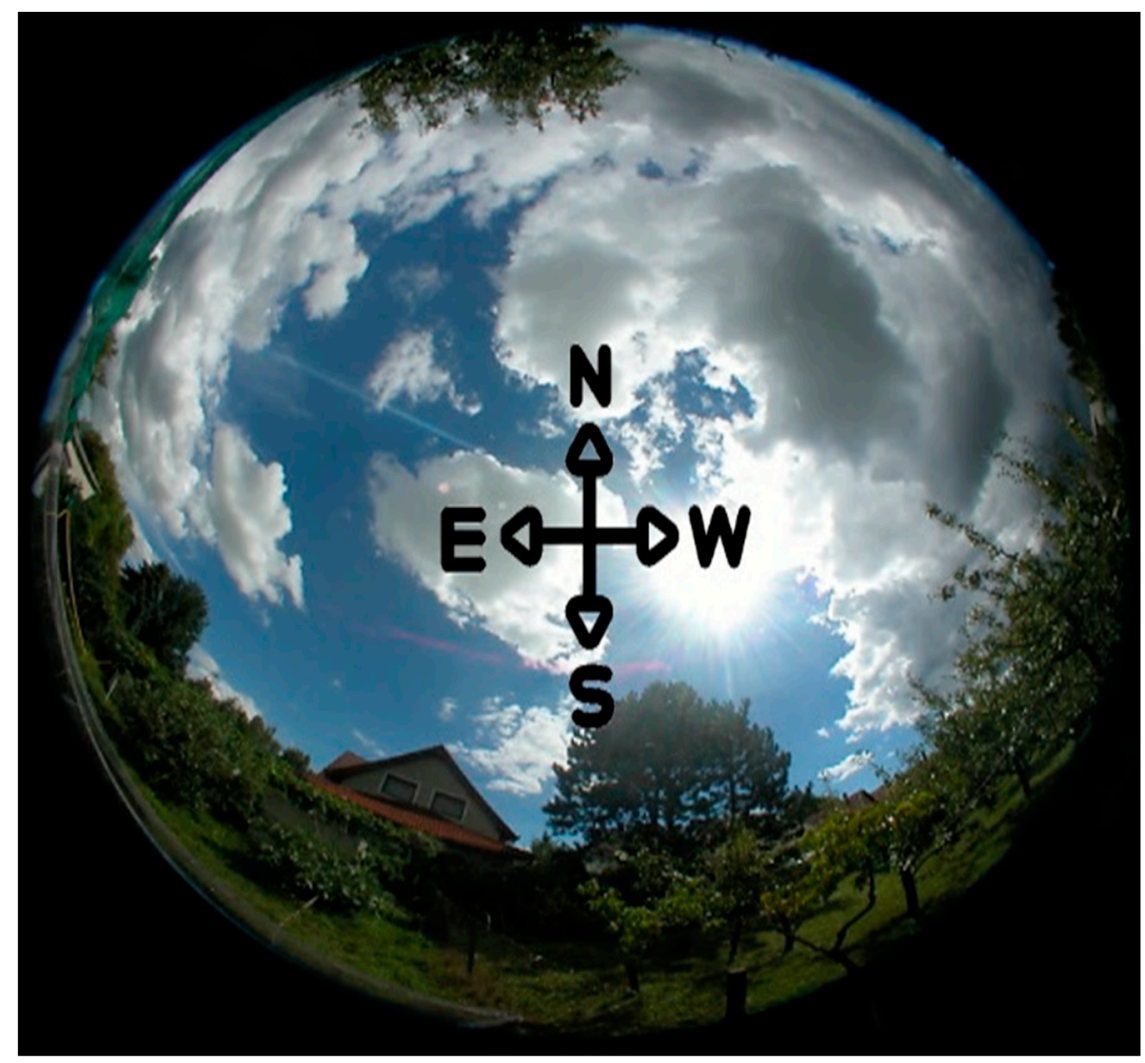

Figure 4. Fisheye view of the measuring station surroundings in the summer afternoon. 
A professional multimeter (Voltcraft VC607) (Conrad Electronic SE, Wernberg-Köblitz, Germany), verified on a LT1021 (Linear Technology Corporation, Milpitas, USA) precision reference, was used for the calibration of the current and the voltage. During the measurements oscillation true maximum point seeking (TMPS) devices were used to optimize the current (A) and the voltage (V) of the PV modules. With these devices it was possible to manually check the maximum power point of the PV modules, thus allowing a correct measurement precision (Figure 5). Moreover, it was also possible to measure the $\mathrm{V}$ and $\mathrm{A}$ values directly without any loss in the TMPS devices.

Within the scope of the present study for the collection of environmental and technical data a GB HOBO (Onset Computer Corporation, Bourne, USA) four-channel analogue data logger, a CR1000 measurement (Campbell Scientific, Inc., Logan, USA) and control datalogger, a PicoLog 1012 (Pico Technology, St Neots, United Kingdom) data acquisition system and a PicoLog 1216 (Pico Technology, St Neots, United Kingdom) acquisition system were used (Figures 5 and 6). The radiation intensity was measured by using an Eppley Black and White Model 4-48 Pyranometer (The Eppley Laboratory, Inc., Newport, USA), Hukseflux LP02 pyranometers (Hukseflux Thermal Sensors B.V., Delft, The Netherlands) and the global horizontal irradiation was taken by an EMS 11 Silicon PV detector (Energy XPRT, Brno, Czech Republic) (Figures 5 and 6).

The angle information of the photovoltaic modules and pyranometers was measured using a digital angle gauge, while the humidity of the air was measured by a HYTE-ANA-1735 (B+B Thermo-Technik GmbH, Donaueschingen, Germany) meter and by an OTT TRH relative humidity sensor (OTT Hydromet GmbH, Kempten, Germany) (Figure 5).

Pt 100 sensors (Conrad Electronic SE, Wernberg-Köblitz, Germany) were used to detect the PV module and air temperatures with the help of the PicoLog devices. A digital LM 35-based precision thermometer (B+B Thermo-Technik $\mathrm{GmbH}$, Donaueschingen, Germany) was used to calibrate the entire measuring circuit. In this research, the temperature values were for informational purposes only, because the temperature values of the PV modules remained stable throughout the experiments (see chapter "2.3. Data Processing and Analysis"). In 2017, 2018 and 2019 measuring stations 'A' and 'B' were used at the same places and times (Figures 5 and 6).

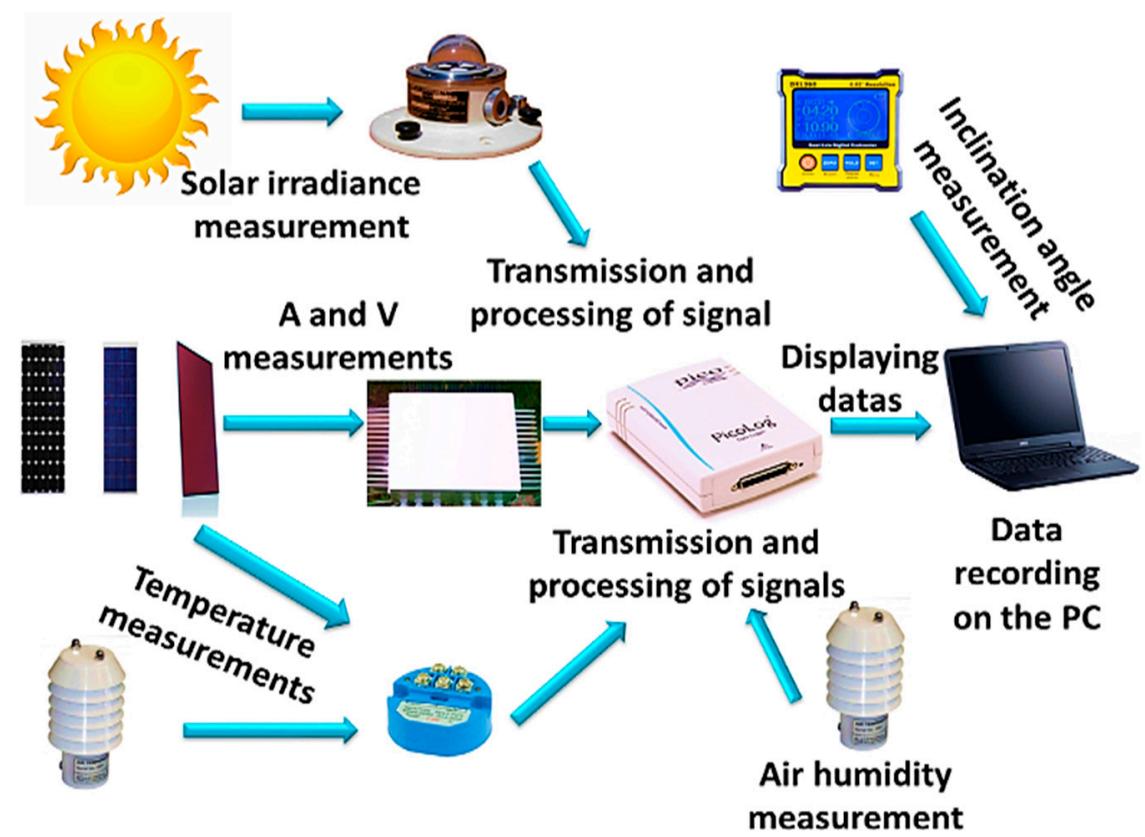

Figure 5. Schematic illustration of PV module measuring station 'A'. 


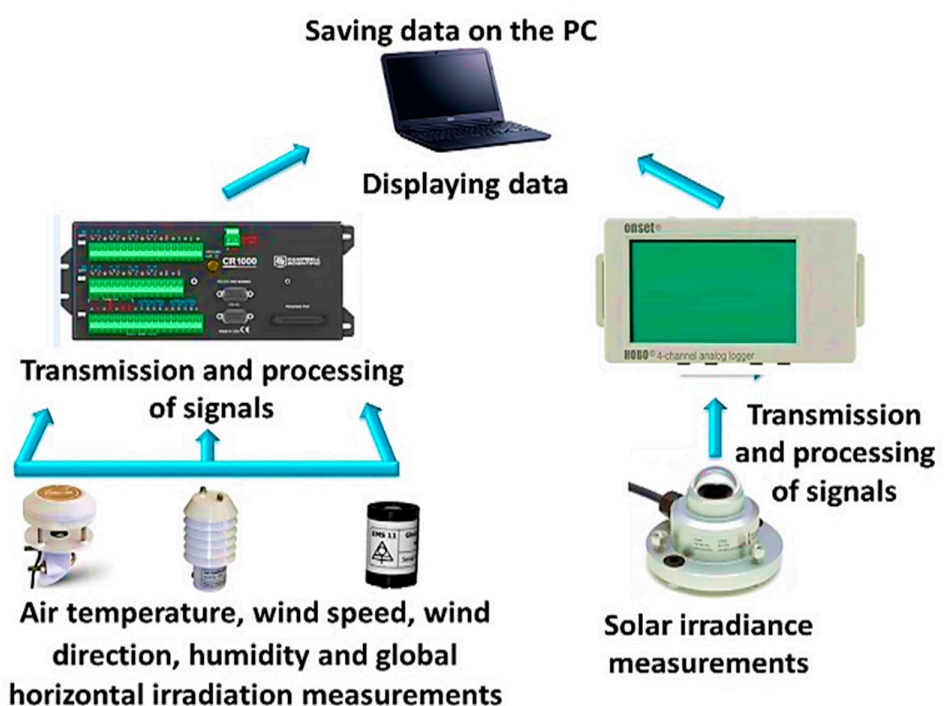

For positioning the photovoltaic modules two linear actuators were used. By a handheld remote control, it was possible to carry out a set of attempts, which were suitable for both horizontal and/or vertical control. The accurate adjustment to the sun was checked by the visible focus point (FP) of the CPV solar module (Figure 7) because at this position the rays of the sun are ideally positioned, perpendicularly to the photovoltaic modules. The measurements at the FP position were used as a reference in order to obtain the power loss as a function of the solar tracking uncertainty angle. Thus, it was possible to measure the technology-specific performance losses in the case of inaccurate sun tracking compared to the ideal position. With inadequate dual tracking devices, it is difficult to provide appropriate measurement conditions, which may lead to erroneous evaluation of the data.

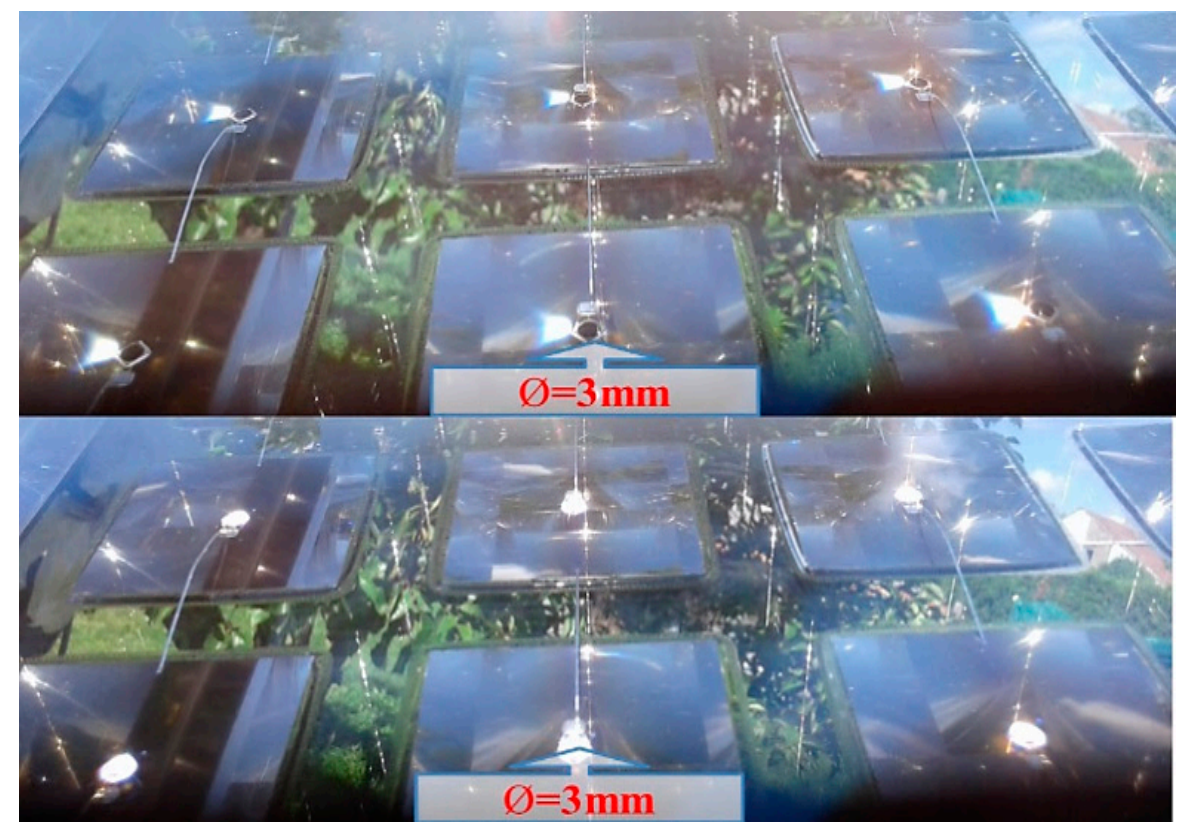

Figure 7. The accuracy of the alignment to the sun can be illustrated with the help of the CPV cells (upper image: incorrect setting; lower image: precise setting).

\subsection{Data Processing and Analysis}

The data collection for the research was carried out in the summers of 2017, 2018 and 2019 on fourteen different days between 11:00 am and 1:30 pm. In each case, measurements were 
taken continuously (every second, station ' $\mathrm{A}$ ') and at an interval of an average of $10 \mathrm{~s}$ (station ' $\mathrm{B}$ '). The measurements of the PV performance and irradiance were made altering the inclination of the PV module towards the north, north-west, west, south-west, south, south-east, east and north-east as follows:

- Module performance and irradiance measurements between the FP and a solar tracking uncertainty of $5^{\circ}$ at 0.5 -degree intervals in all directions to find the performance insensitivity threshold of the $\mathrm{m}-\mathrm{Si}, \mathrm{p}-\mathrm{Si}$ and a-Si technologies. It was possible to measure the performance values directly without any loss in the TMPS devices.

- Module performance and irradiance measurements between the FP and a solar tracking uncertainty of $30^{\circ}$ by moving in 10-degree steps in all directions to see the technology-specific performance properties of $\mathrm{m}-\mathrm{Si}, \mathrm{p}-\mathrm{Si}$ and a-Si technologies. It was possible to measure the performance values directly without any loss in the TMPS devices.

For all angles the starting position of the PV modules was the FP of the CPV solar cells, after which the aforementioned orientations, radiation and performance data were measured. The performance output for each position was measured over $10 \mathrm{~s}$, and switching to the next measurement lasted for 2-20 s. Due to the switching of the measuring instruments, it was necessary to wait about $6 \mathrm{~s}$. During the measurements this method made it possible to eliminate the effect of the changing environmental conditions (for example, temperature changes of PV modules), since the starting point for each measurement was the FP.

Appropriate measurements of yield loss for a solar tracking position from the FP to a solar tracking uncertainty of $5^{\circ}$ were achieved during 2018 and 2019. In the summers of both years, measurements were performed 20 times for each direction. These data were averaged and checked using relative standard deviation (CV\%). A relative standard deviation between 0 and $10 \%$ shows homogeneous conditions, between 10.1 and $20 \%$ it shows a medium variability, between 20.1 and $30 \%$ it shows strong variability, while above $30.1 \%$ it is related to strongly heterogeneous conditions [52]. For all measurements, the relative standard deviation of the averaged data was below $1 \%$, which was an excellent result. To manage, evaluate and analyse the data Microsoft Excel (version: 2016, Redmond, DC, USA), PicoScope (version: R5.23.0, St Neots, UK), Matlab (version: R2017a, Natick, MA, USA) and SPSS Statistics (version: 24, Armonk, NY, USA) software were used. It is difficult to detect systematic mistakes but these phenomena do not increase the deviation of the measurements. The given measuring accuracy and calibration (which should be independent of the measuring system) of the measuring devices can help solve this problem.

\section{Results}

\subsection{The Performance Insensitivity Threshold of Selected PV Technologies, as a Function of Direction}

The measurement results showed the performance insensitivity thresholds of the m-Si, p-Si and a-Si modules depending on alignment changes. In the case of same-direction changes around the FP the performance deviations were not the same. Figures 8-10 provide information for the easier interpretation of the solar tracking sensors' inaccuracy. Figures 8-10 show no variation as a function of the gap relative to the focus point (FP) for any of the modules if the angle of deviation is below $3^{\circ}$. Indeed, in every direction and for every technology, there is still $100 \%$ of performance (pink color) below $3^{\circ}$ of "offset" compared to the FP and less than $2 \%$ of loss below $5^{\circ}$. The most indifferent orientation was north-south up to $5^{\circ}$. The east and west measurements showed a $1 \%$ power reduction in the case of $4.5^{\circ}-5^{\circ}$ compared to the FP. The north-west orientation was the most sensitive setting with a $2 \%$ performance change in the case of a change in alignment of between $4.5^{\circ}$ and $5^{\circ}$. The average values were the same for all three technologies up to $5^{\circ}$ (Figures $8-10$ ). Up to a deviation of $10^{\circ}$ the $\mathrm{m}-\mathrm{Si}, \mathrm{p}-\mathrm{Si}$ and a-Si module data showed a $1-4 \%$ change in power. That was the limit where the performance features of the measured technologies were almost the same. Only the p-Si technology differs by $1 \%$ in the case of the south-west orientation. In the case of a $20^{\circ}$ change it becomes more 
visible which orientation causes greater deviation. The least sensitive orientation is south-north, where the crystalline technologies showed $4 \%$, while the a-Si one showed $5 \%$ power reduction compared to the FP. In the case of the east-west orientation the values were reduced by $5-8 \%$ (Figures $8-10$ ). The measurements performed for inclination changes towards north-west, south-west, south-east, and north-east showed about an $8-12 \%$ performance loss for the crystalline modules, while the a-Si module seemed more sensitive with $11-16 \%$. It can be seen that when the solar tracking uncertainty was increased to $20^{\circ}$, the orientation sensitivity of the technologies used became measurable. These features were also observable for a $30^{\circ}$ uncertainty, but the performance change showed a greater difference. In this case, the biggest difference was again seen for the north-west, south-west, south-east, and north-east directions (Figures 8-10). In the cases of solar tracking deviations of $20^{\circ}$ and $30^{\circ}$, it is not only the technology-specific differences that can be seen, but also the fact that the western deviation is $1-5 \%$ more sensitive compared to the eastern direction (Figures $8-10$ ). The explanation is not only that the direct and diffuse radiation from the sun changes with the orientation of the module, but there is also an influence by reflected radiation from the surroundings.

Our aim was to publish our experimental and theoretical results in as much detail as possible. This method ensures the reproducibility of experimental results for other researchers. These results may make the planning of solar tracking sensor investments easier and help with the estimate calculations of total investment and operational costs and their return concerning monocrystalline, polycrystalline and amorphous silicon photovoltaic systems. The results also provide guidance for the tracking error values of solar tracking sensors.

3.2. Polynomial Regression Models of Dual-Axis Solar Tracking m-Si, $p$-Si and a-Si Systems between $0-30^{\circ}$ of Deviation Compared to the FP

Polynomial regression models (Tables 3-8) have been created from the results of Figures 8-10 by Matlab software. This method ensures the reproducibility of experimental results for other researchers. Other regression methods have been also tested (logarithmic, quadratic, exponential, multivariable) for the data analysis, nevertheless, the most accurate fit came from the polynomial regression model at the highest R-squared value.

With the help of these models, a context has been created for the effects of solar radiation changes caused by inaccurate dual-axis solar tracking systems on $\mathrm{m}-\mathrm{Si}, \mathrm{p}-\mathrm{Si}$ and a-Si performance. Using a pyranometer and applying the contexts for deviations between the FP and $30^{\circ}$ in all directions anyone can estimate the performance changes for these technologies. The R-square values in the case of the effect of solar radiation changes on m-Si performance showed an almost perfect fit (Tables 3-5).

Using the polynomial regression models, we developed equations which describe the performance of $\mathrm{m}-\mathrm{Si}, \mathrm{p}-\mathrm{Si}$ or a-Si modules as a function of solar tracking uncertainties up to $30^{\circ}$. Using the values of directional changes and the equations anyone can estimate the performance changes for these technologies for dual-axis solar tracking systems. The R-square values obtained for the m-Si performance represented an almost perfect fit (Tables 6-8). 
Performance insensitivity thresholds (pink color $=\mathbf{1 0 0} \%$, no change in power)

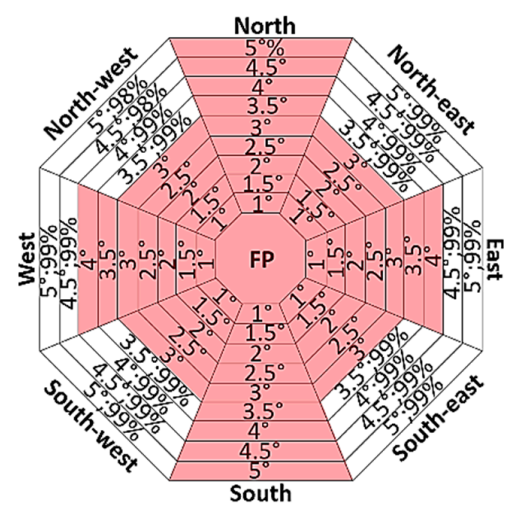

Performance changes of $\mathrm{m}-\mathrm{Si}$ technology depending on direction changes compared to the FP

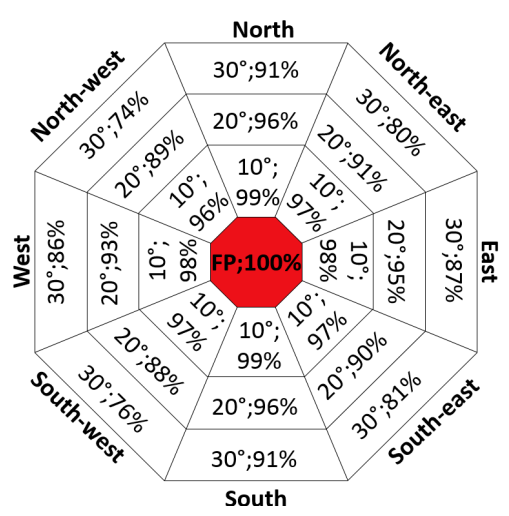

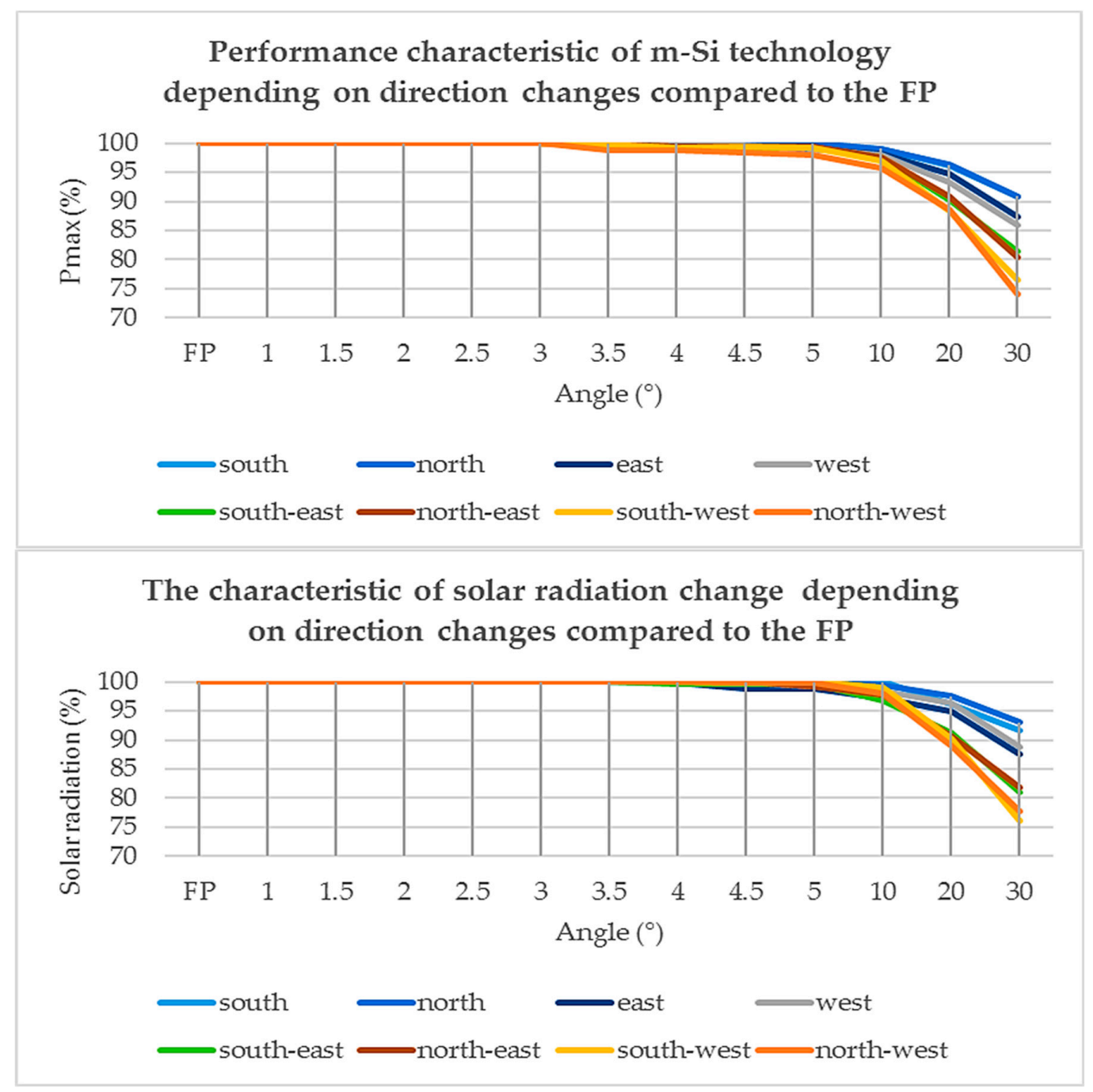

Figure 8. The performance insensitivity thresholds, the performance changes, the solar radiation features and the performance characteristics of $\mathrm{m}$-Si technology depending on directional changes compared to the focus point (FP). 
Performance insensitivity thresholds (pink color $=100 \%$, no change in power)

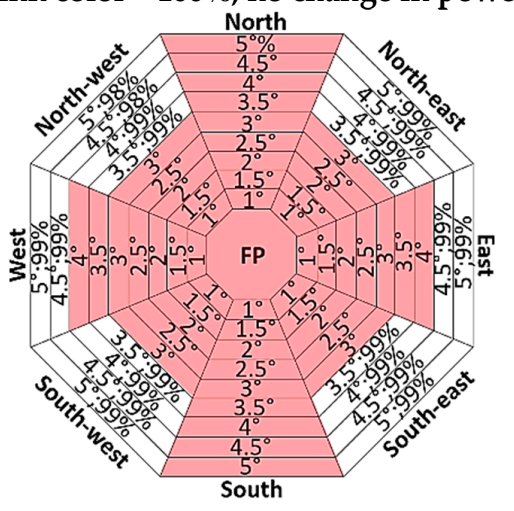

Performance changes of p-Si technology depending on direction changes compared to the FP

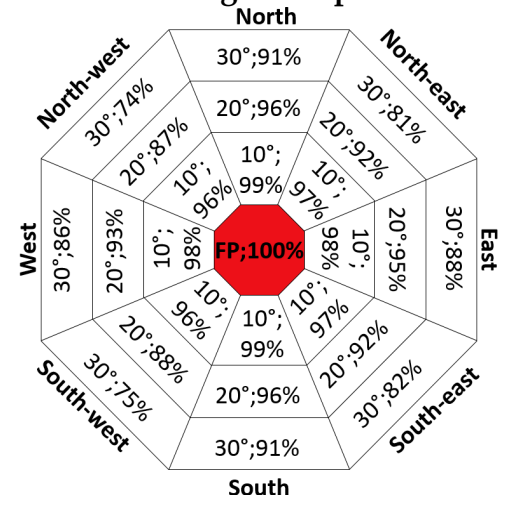

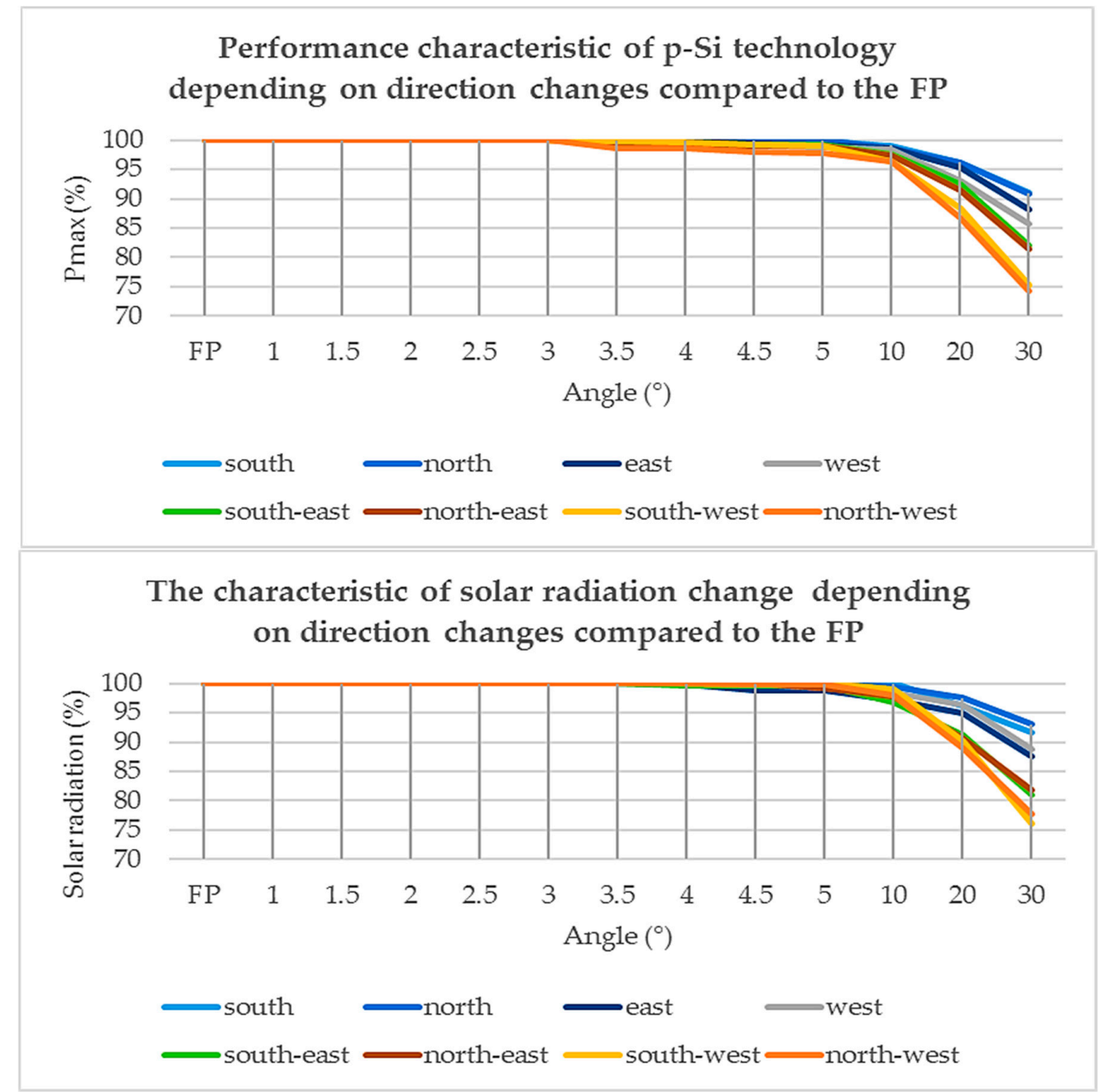

Figure 9. The performance insensitivity thresholds, the performance changes, the solar radiation features and the performance characteristics of $\mathrm{p}$-Si technology depending on directional changes compared to the FP. 
Performance insensitivity thresholds (pink color $=100 \%$, no change in power)

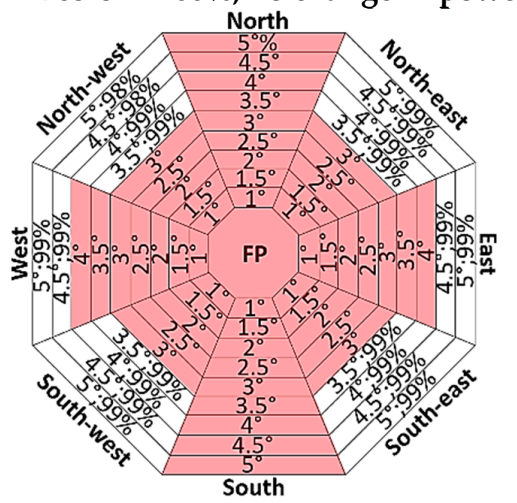

Performance changes of a-Si technology depending on direction changes compared to the FP

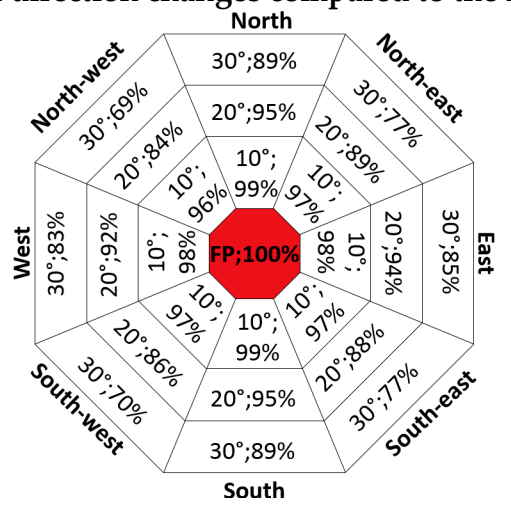

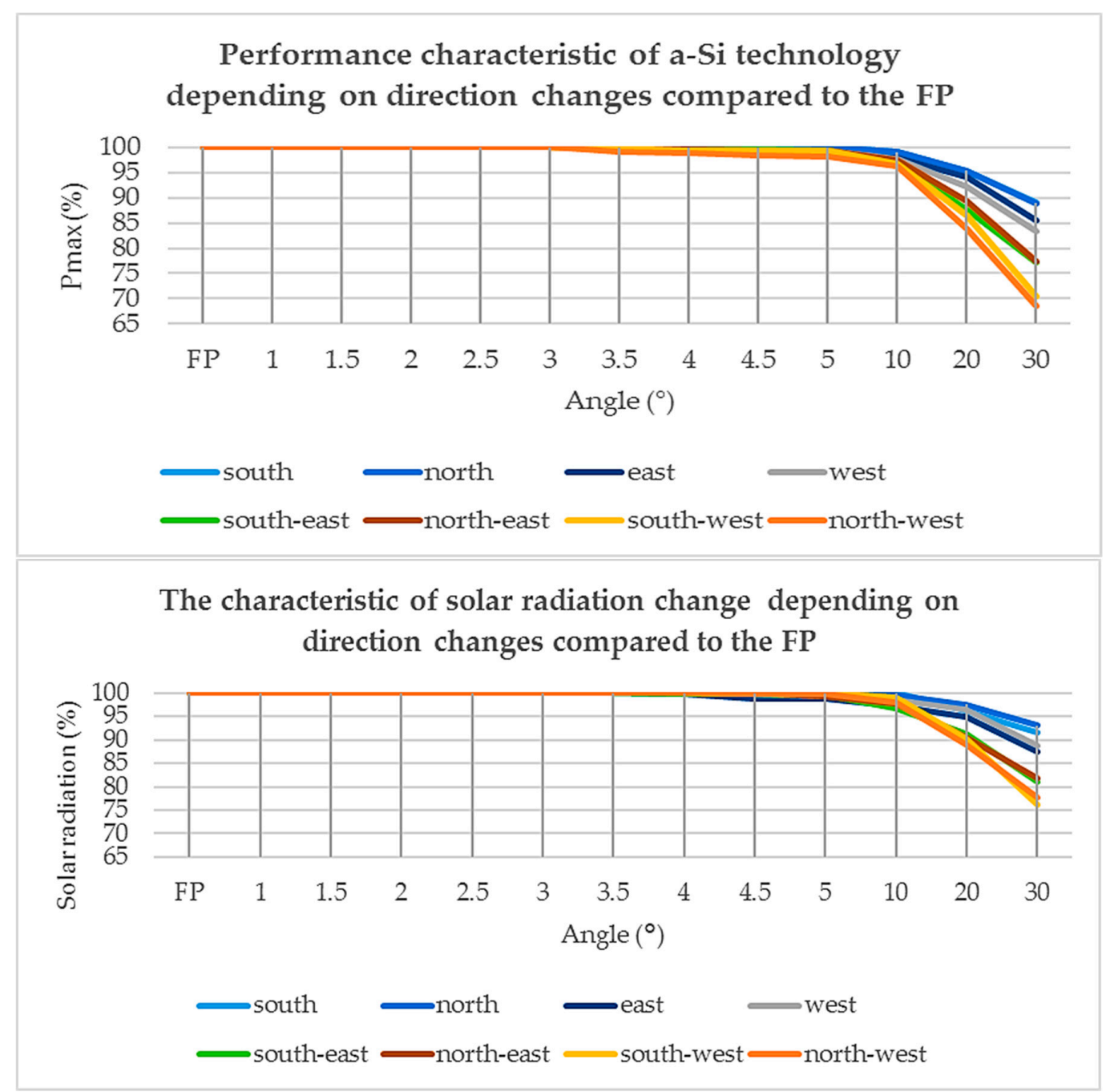

Figure 10. The performance insensitivity thresholds, the performance changes, the solar radiation features and the performance characteristics of a-Si technology depending on directional changes compared to the FP. 
Table 3. The effect of solar radiation changes on $\mathrm{m}-\mathrm{Si}$ performance. $(\mathrm{x}=$ change in solar radiation $(\%)$, $\mathrm{FP}=100 \%, 80 \%=20 \%$ change in solar radiation; $\mathrm{f}(\mathrm{x})=$ percentage value of the performance compared to the FP).

\begin{tabular}{|c|c|c|c|}
\hline Description & Equation & Numerical Results for Modeling & R-Square \\
\hline South & \multirow{8}{*}{$\begin{array}{c}f(x)=p 1 \times x^{2}+p 2 \\
\times x+p 3\end{array}$} & $\begin{array}{c}\mathrm{p} 1=-0.01395 \\
\mathrm{p} 2=3.748 \\
\mathrm{p} 3=-135.5\end{array}$ & 0.9889 \\
\hline North & & $\begin{array}{c}\mathrm{p} 1=0.04104 \\
\mathrm{p} 2=-6.601 \\
\mathrm{p} 3=349.7\end{array}$ & 0.9996 \\
\hline East & & $\begin{array}{c}\mathrm{p} 1=-0.01577 \\
\mathrm{p} 2=3.978 \\
\mathrm{p} 3=-140.1\end{array}$ & 0.9947 \\
\hline West & & $\begin{array}{c}\mathrm{p} 1=0.05651 \\
\mathrm{p} 2=-9.401 \\
\mathrm{p} 3=475.1\end{array}$ & 0.9939 \\
\hline South-east & & $\begin{array}{c}\mathrm{p} 1=0.006652 \\
\mathrm{p} 2=-0.2319 \\
\text { p3 }=56.61\end{array}$ & 0.9953 \\
\hline South-west & & $\begin{array}{c}\mathrm{p} 1=0.01358 \\
\mathrm{p} 2=-1.421 \\
\mathrm{p} 3=105.9\end{array}$ & 0.9943 \\
\hline North-east & & $\begin{array}{c}\mathrm{p} 1=-0.01195 \\
\mathrm{p} 2=3.244 \\
\mathrm{p} 3=-105\end{array}$ & 0.9987 \\
\hline North-west & & $\begin{array}{c}\mathrm{p} 1=-0.009231 \\
\mathrm{p} 2=2.776 \\
\mathrm{p} 3=-85.95\end{array}$ & 0.9880 \\
\hline $\begin{array}{l}\text { Example of calculation result, south-east, } \\
80 \% \text { change in solar radiation [\%] }\end{array}$ & $\begin{array}{l}81 \%=\mathrm{p} 1 \times 80^{2}+ \\
\mathrm{p} 2 \times 80+\mathrm{p} 3\end{array}$ & & \\
\hline
\end{tabular}

Table 4. The effect of solar radiation changes on $\mathrm{p}-\mathrm{Si}$ performance $(\mathrm{x}=$ change in solar radiation $(\%)$, $\mathrm{FP}=100 \%, 80 \%=20 \%$ change in solar radiation; $\mathrm{f}(\mathrm{x})=$ percentage value of the performance compared to the FP).

\begin{tabular}{|c|c|c|c|}
\hline Description & Equation & Numerical Results for Modeling & R-Square \\
\hline South & \multirow{8}{*}{$\begin{array}{c}f(x)=p 1 \times x^{2}+p 2 \\
\quad \times x+p 3\end{array}$} & $\begin{array}{c}\mathrm{p} 1=-0.01918 \\
\mathrm{p} 2=4.745 \\
\mathrm{p} 3=-182.8\end{array}$ & 0.9910 \\
\hline North & & $\begin{array}{c}\mathrm{p} 1=0.06783 \\
\mathrm{p} 2=-11.8 \\
\text { p3 }=601.7\end{array}$ & 0.9963 \\
\hline East & & $\begin{array}{c}\mathrm{p} 1=-0.02172 \\
\mathrm{p} 2=5.032 \\
\mathrm{p} 3=-185.9\end{array}$ & 0.9926 \\
\hline West & & $\begin{array}{c}\mathrm{p} 1=0.05355 \\
\mathrm{p} 2=-8.834 \\
\mathrm{p} 3=447.7\end{array}$ & 0.9827 \\
\hline South-east & & $\begin{array}{c}\mathrm{p} 1=-0.009841 \\
\mathrm{p} 2=2.717 \\
\mathrm{p} 3=-73.46\end{array}$ & 0.9985 \\
\hline South-west & & $\begin{array}{c}\mathrm{p} 1=0.01107 \\
\mathrm{p} 2=-0.9367 \\
\mathrm{p} 3=82.5\end{array}$ & 0.9910 \\
\hline North-east & & $\begin{array}{c}\mathrm{p} 1=-0.01228 \\
\mathrm{p} 2=3.236 \\
\mathrm{p} 3=-101.1\end{array}$ & 0.9957 \\
\hline North-west & & $\begin{array}{c}\mathrm{p} 1=0.002913 \\
\mathrm{p} 2=0.6102 \\
\mathrm{p} 3=9.131\end{array}$ & 0.9898 \\
\hline $\begin{array}{c}\text { Example of calculation result, south-east, } \\
20 \% \text { change in solar radiation [\%] }\end{array}$ & $\begin{array}{l}81 \%=\mathrm{p} 1 \times 80^{2}+ \\
\mathrm{p} 2 \times 80+\mathrm{p} 3\end{array}$ & & \\
\hline
\end{tabular}


Table 5. The effect of solar radiation changes on a-Si performance ( $x=$ change in solar radiation $(\%)$, $\mathrm{FP}=100 \%, 80 \%=20 \%$ change in solar radiation; $\mathrm{f}(\mathrm{x})=$ percentage value of the performance compared to the FP).

\begin{tabular}{|c|c|c|c|}
\hline Description & Equation & Numerical Results for Modeling & R-Square \\
\hline South & \multirow{8}{*}{$\begin{aligned} f(x)= & p 1 \times x^{2}+p 2 \\
& \times x+p 3\end{aligned}$} & $\begin{array}{c}\mathrm{p} 1=-0.01557 \\
\mathrm{p} 2=4.28 \\
\mathrm{p} 3=-172.4\end{array}$ & 0.9933 \\
\hline North & & $\begin{array}{c}\mathrm{p} 1=0.0601 \\
\mathrm{p} 2=-10 \\
\mathrm{p} 3=499.2\end{array}$ & 1 \\
\hline East & & $\begin{array}{c}\mathrm{p} 1=-0.01756 \\
\mathrm{p} 2=4.468 \\
\mathrm{p} 3=-171.3\end{array}$ & 0.9948 \\
\hline West & & $\begin{array}{c}\text { p1 }=0.06519 \\
\text { p2 }=-10.82 \\
\text { p3 }=530.1\end{array}$ & 0.9929 \\
\hline South-east & & $\begin{array}{c}\mathrm{p} 1=0.01088 \\
\mathrm{p} 2=-0.7589 \\
\text { p3 }=67.21\end{array}$ & 0.9942 \\
\hline South-west & & $\begin{array}{c}\text { p1 }=0.01088 \\
\text { p2 }=-0.6964 \\
\text { p3 }=60.43\end{array}$ & 0.9956 \\
\hline North-east & & $\begin{array}{c}\mathrm{p} 1=-0.01392 \\
\mathrm{p} 2=3.776 \\
\mathrm{p} 3=-138.5\end{array}$ & 0.9990 \\
\hline North-west & & $\begin{array}{c}\mathrm{p} 1=0.004485 \\
\mathrm{p} 2=0.5934 \\
\mathrm{p} 3=-4.726\end{array}$ & 0.9957 \\
\hline $\begin{array}{c}\text { Example of calculation result, south-east, } \\
20 \% \text { change in solar radiation [\%] }\end{array}$ & $\begin{array}{c}76 \%=\mathrm{p} 1 \times 80^{2}+ \\
\mathrm{p} 2 \times 80+\mathrm{p} 3\end{array}$ & - & \\
\hline
\end{tabular}

Table 6. The effect of directional changes on $\mathrm{m}$-Si performance $\left(\mathrm{x}=\right.$ change in orientation $\left(^{\circ}\right)$; $f(x)=$ percentage value of the performance compared to the FP).

\begin{tabular}{|c|c|c|c|}
\hline Description & Equation & Numerical Results for Modeling & R-Square \\
\hline South & \multirow{8}{*}{$\begin{aligned} f(x)= & p 1 \times x^{4}+p 2 \times x^{3}+p 3 \\
& \times x^{2}+p 4 \times x+p 5\end{aligned}$} & $\begin{array}{c}\mathrm{p} 1=-1.683 \times 10^{-5} \\
\mathrm{p} 2=0.0009611 \\
\mathrm{p} 3=-0.02697 \\
\mathrm{p} 4=0.09686 \\
\text { p5 }=99.95\end{array}$ & \multirow{2}{*}{0.9998} \\
\hline North & & $\begin{array}{c}\mathrm{p} 1=-1.877 \times 10^{-5} \\
\mathrm{p} 2=0.0009883 \\
\mathrm{p} 3=-0.02603 \\
\text { p } 4=0.09122 \\
\text { p5 }=99.95\end{array}$ & \\
\hline East & & $\begin{array}{c}\mathrm{p} 1=-4.017 \times 10^{-5} \\
\mathrm{p} 2=0.001883 \\
\text { p3 }=-0.03404 \\
\text { p4 }=-0.01403 \\
\text { p5 }=100.1\end{array}$ & 0.9979 \\
\hline West & & $\begin{array}{c}\mathrm{p} 1=-2.936 \times 10^{-5} \\
\mathrm{p} 2=0.001704 \\
\mathrm{p} 3=-0.04316 \\
\text { p4 }=0.08324 \\
\text { p5 }=100\end{array}$ & 0.9987 \\
\hline South-east & & $\begin{array}{c}\mathrm{p} 1=2.095 \times 10^{-5} \\
\mathrm{p} 2=-0.0007642 \\
\mathrm{p} 3=-0.01447 \\
\mathrm{p} 4=-0.06451 \\
\text { p5 }=100.1\end{array}$ & 0.9994 \\
\hline South-west & & $\begin{array}{c}\mathrm{p} 1=-3.515 \times 10^{-6} \\
\mathrm{p} 2=0.0004726 \\
\mathrm{p} 3=-0.03775 \\
\text { p } 4=0.01547 \\
\text { p5 }=100.1\end{array}$ & 0.9996 \\
\hline North-east & & $\begin{array}{c}\mathrm{p} 1=-8.536 \times 10^{-6} \\
\mathrm{p} 2=0.0006003 \\
\mathrm{p} 3=-0.03319 \\
\mathrm{p} 4=0.03196 \\
\text { p5 }=100\end{array}$ & 0.9997 \\
\hline North-west & & $\begin{array}{c}\mathrm{p} 1=-6.333 \times 10^{-5} \\
\mathrm{p} 2=0.002912 \\
\mathrm{p} 3=-0.05449 \\
\text { p4 }=-0.1513 \\
\text { p5 }=100.3\end{array}$ & 0.9987 \\
\hline $\begin{array}{c}\text { Example of calculation result, south-east, } \\
20 \% \text { direction change [\%] }\end{array}$ & $\begin{array}{c}90 \%=\mathrm{p} 1 \times 20^{4}+\mathrm{p} 2 \times 20^{3}+ \\
\mathrm{p} 3 \times 20^{2}+\mathrm{p} 4 \times 20+\mathrm{p} 5\end{array}$ & & \\
\hline
\end{tabular}


Table 7. The effect of directional changes on p-Si performance $\left(x=\right.$ change in orientation $\left(^{\circ}\right)$; $f(x)=$ percentage value of the performance compared to the FP).

\begin{tabular}{|c|c|c|c|}
\hline Description & Equation & $\begin{array}{c}\text { Numerical Results for } \\
\text { Modeling }\end{array}$ & R-Square \\
\hline South & $\begin{array}{c}f(x)=p 1 \times x^{4}+p 2 \times x^{3}+p 3 \times \\
x^{2}+p 4 \times x+p 5\end{array}$ & $\begin{array}{c}\mathrm{p} 1=-1.17 \times 10^{-5} \\
\mathrm{p} 2=0.0006521 \\
\text { p3 }=-0.02167 \\
\text { p4 }=0.07924 \\
\text { p5 }=99.96\end{array}$ & 0.9999 \\
\hline North & $\begin{array}{c}f(x)=p 1 \times x^{3}+p 2 \times x^{2}+p 3 \times \\
x+p 4\end{array}$ & $\begin{array}{c}\mathrm{p} 1=-2.369 \times 10^{-5} \\
\mathrm{p} 2=-0.008792 \\
\mathrm{p} 3=-0.02042 \\
\mathrm{p} 4=100.1\end{array}$ & 0.9956 \\
\hline East & $\begin{array}{c}f(x)=p 1 \times x^{4}+p 2 \times x^{3}+p 3 \times \\
x^{2}+p 4 \times x+p 5\end{array}$ & $\begin{array}{c}\mathrm{p} 1=-1.88 \times 10^{-5} \\
\mathrm{p} 2=0.0007663 \\
\text { p3 }=-0.01851 \\
\text { p4 }=-0.0239 \\
\text { p5 }=100.1\end{array}$ & 0.9981 \\
\hline West & $\begin{array}{c}f(x)=p 1 \times x^{3}+p 2 \times x^{2}+p 3 \times \\
x+p 4\end{array}$ & $\begin{array}{c}\mathrm{p} 1=-6.694 \times 10^{-5} \\
\mathrm{p} 2=-0.01025 \\
\text { p3 }=-0.1163 \\
\text { p4 }=100.1\end{array}$ & 0.9935 \\
\hline South-east & & $\begin{array}{c}\mathrm{p} 1=-3.306 \times 10^{-5} \\
\mathrm{p} 2=0.001555 \\
\text { p3 }=-0.03691 \\
\text { p4 }=-0.002006 \\
\text { p5 }=100.1\end{array}$ & 0.9996 \\
\hline South-west & $\begin{array}{c}f(x)=p 1 \times x^{4}+p 2 \times x^{3}+p 3 \times \\
x^{2}+p 4 \times x+p 5\end{array}$ & $\begin{array}{c}\mathrm{p} 1=-2.717 \times 10^{-5} \\
\text { p2 }=0.001542 \\
\text { p3 }=-0.04935 \\
\text { p4 }=0.001848 \\
\text { p5 }=100.1\end{array}$ & 0.9985 \\
\hline North-east & & $\begin{array}{c}\mathrm{p} 1=-2.624 \times 10^{-5} \\
\mathrm{p} 2=0.001321 \\
\mathrm{p} 3=-0.0354 \\
\mathrm{p} 4=-0.03995 \\
\mathrm{p} 5=100.1\end{array}$ & 0.9993 \\
\hline North-west & $\begin{array}{c}f(x)=p 1 \times x^{3}+p 2 \times x^{2}+p 3 \times \\
x+p 4\end{array}$ & $\begin{array}{c}\mathrm{p} 1=-2.968 \times 10^{-5} \\
\mathrm{p} 2=-0.01921 \\
\text { p3 }=-0.2668 \\
\text { p4 }=100.2\end{array}$ & 0.9961 \\
\hline $\begin{array}{l}\text { Example of calculation } \\
\text { result, south-east, } 20 \% \\
\text { direction change [\%] }\end{array}$ & $\begin{array}{c}92 \%=\mathrm{p} 1 \times 20^{4}+\mathrm{p} 2 \times 20^{3}+\mathrm{p} 3 \\
\quad \times 20^{2}+\mathrm{p} 4 \times 20+\mathrm{p} 5\end{array}$ & & \\
\hline
\end{tabular}


Table 8. The effect of directional changes on a-Si performance $\left(x=\right.$ change in orientation $\left(^{\circ}\right)$; $f(x)=$ percentage value of the performance compared to the FP).

\begin{tabular}{|c|c|c|c|}
\hline Description & Equation & $\begin{array}{l}\text { Numerical Results for } \\
\text { Modeling }\end{array}$ & R-Square \\
\hline South & $\begin{array}{c}f(x)=p 1 \times x^{4}+p 2 \times x^{3}+p 3 \times \\
x^{2}+p 4 \times x+p 5\end{array}$ & $\begin{array}{c}\mathrm{p} 1=2.646 \times 10^{-7} \\
\mathrm{p} 2=5.382 \times 10^{-5} \\
\mathrm{p} 3=-0.01624 \\
\mathrm{p} 4=0.06834 \\
\text { p5 }=99.96\end{array}$ & 0.9999 \\
\hline North & $\begin{array}{c}f(x)=p 1 \times x^{3}+p 2 \times x^{2}+p 3 \times \\
x+p 4\end{array}$ & $\begin{array}{c}\mathrm{p} 1=3.102 \times 10^{-5} \\
\mathrm{p} 2=-0.01546 \\
\mathrm{p} 3=0.06449 \\
\mathrm{p} 4=99.97\end{array}$ & 0.9998 \\
\hline East & & $\begin{array}{c}\mathrm{p} 1=-4.779 \times 10^{-5} \\
\mathrm{p} 2=0.002246 \\
\mathrm{p} 3=-0.04004 \\
\text { p4 }=-0.02006 \\
\text { p5 }=100.1\end{array}$ & 0.9984 \\
\hline West & & $\begin{array}{c}\mathrm{p} 1=-3.919 \times 10^{-5} \\
\text { p2 }=0.002307 \\
\text { p3 }=-0.05705 \\
\text { p4 }=0.1432 \\
\text { p5 }=99.97\end{array}$ & 0.9994 \\
\hline South-east & $\begin{array}{c}f(x)=p 1 \times x^{4}+p 2 \times x^{3}+p 3 \times \\
x^{2}+p 4 \times x+p 5\end{array}$ & $\begin{array}{c}\mathrm{p} 1=3.445 \times 10^{-5} \\
\mathrm{p} 2=-0.001102 \\
\text { p3 }=-0.02458 \\
\text { p4 }=0.03649 \\
\text { p5 }=100\end{array}$ & 0.9999 \\
\hline South-west & & $\begin{array}{c}\mathrm{p} 1=-1.174 \times 10^{-6} \\
\text { p2 }=0.0002058 \\
\text { p3 }=-0.03832 \\
\text { p4 }=0.01014 \\
\text { p5 }=100.1\end{array}$ & 0.9996 \\
\hline North-east & & $\begin{array}{c}\text { p1 }=7.699 \times 10^{-6} \\
\text { p2 }=-0.0002437 \\
\text { p3 }=-0.02453 \\
\text { p4 }=-0.01247 \\
\text { p5 }=100.1\end{array}$ & 0.9998 \\
\hline North-west & & $\begin{array}{c}\mathrm{p} 1=7.456 \times 10^{-5} \\
\text { p2 }=-0.003751 \\
\text { p3 }=0.02249 \\
\text { p4 }=-0.373 \\
\text { p5 }=100.4\end{array}$ & 0.9984 \\
\hline $\begin{array}{l}\text { Example of calculation } \\
\text { result, south-east, } 20 \% \\
\text { direction change [\%] }\end{array}$ & $\begin{array}{c}88 \%=\mathrm{p} 1 \times 20^{4}+\mathrm{p} 2 \times 20^{3}+\mathrm{p} 3 \\
\times 20^{2}+\mathrm{p} 4 \times 20+\mathrm{p} 5\end{array}$ & & \\
\hline
\end{tabular}

\section{Conclusions}

In our research, we studied the positioning features of polycrystalline (p-Si), monocrystalline (m-Si), and amorphous silicon (a-Si) modules relative to the FP of a reference CPV module under real meteorological conditions using a dual tracking system. The measurement results indicated that the performance insensitivity thresholds of $\mathrm{m}-\mathrm{Si}, \mathrm{p}-\mathrm{Si}$, and a-Si modules depend on the direction of the changes. According to the relevant literature, solar tracking system devices are very popular and always perform at more than $98.5 \%$ of their full tracking efficiency even when the aim of the device 
is off by $10^{\circ}$. Nevertheless, the deviations in performance showed a significant dependence on the azimuthal direction. The most indifferent orientation was the north-south, while the most sensitive settings were the north-west, south-west, south-east, and north-east orientations. According to the results, there is no variation as a function of the deviation relative to the focus point for any of the module technologies examined if the angle of variance is below $3^{\circ}$. This also provides guidance for the tracking error values of solar tracking sensors. Although nowadays there are many easily and cheaply available solar tracking systems and sensors, their tracking error tolerance is at least $1.5^{\circ}$. The $3^{\circ}$ threshold of insensitivity indicates that it is not economically sensible to make solar tracking sensors more sensitive than that. This information may contribute to the achievement of economically optimal investments. With the help of the new evidence delivered by the study, it may become easier to plan solar tracking sensor equipment and to assess the total investment and operational costs and their return in the case of $\mathrm{m}-\mathrm{Si}$, $\mathrm{p}-\mathrm{Si}$, and a-Si PV systems.

In the future, CPV modules will be examined. According to preliminary measurements, this technology is much more sensitive to changes in orientation, and from the point of view of future investments, it would be important to determine its insensitivity.

Author Contributions: H.Z. was mainly responsible for the technical, experimental and modelling aspects, and conceived and designed the manuscript. All authors contributed equally in the analysis of the data and the writing and revision of the manuscript.

Acknowledgments: The publication is supported by the EFOP-3.6.3-VEKOP-16-2017-00008 project. The project is co-financed by the European Union and the European Social Fund. This research was supported by the Austrian Hungarian Action Foundation [AÖU Project 99ÖU3]. The work was carried out in the University of Pécs, János Szentágothai Research Centre, Energy Design research Group.

Conflicts of Interest: The authors declare no conflicts of interest.

\section{References}

1. Dominković, D.F.; Bačeković, I.; Sveinbjörnsson, D.; Pedersen, A.S.; Krajačić, G. On the way towards smart energy supply in cities: The impact of interconnecting geographically distributed district heating grids on the energy system. Energy 2017, 137, 941-960. [CrossRef]

2. Kordmahaleh, A.A.; Naghashzadegan, M.; Javaherdeh, K.; Khoshgoftar, M. Design of a 25 MWe Solar Thermal Power Plant in Iran with Using Parabolic Trough Collectors and a Two-Tank Molten Salt Storage System. Int. J. Photoenergy 2017, 2017, 1-11. [CrossRef]

3. Noman, A.M.; Addoweesh, K.E.; Alolah, A.I. Simulation and Practical Implementation of ANFIS-Based MPPT Method for PV Applications Using Isolated Ćuk Converter. Int. J. Photoenergy 2017, 2017, 1-15. [CrossRef]

4. Daliento, S.; Chouder, A.; Guerriero, P.; Pavan, A.M.; Mellit, A.; Moeini, R.; Tricoli, P. Monitoring, Diagnosis, and Power Forecasting for Photovoltaic Fields: A Review. Int. J. Photoenergy 2017, 2017, 1-13. [CrossRef]

5. Sefa, İ.; Demirtas, M.; Çolak, İ. Application of one-axis sun tracking system. Energy Convers. Manag. 2009, 50, 2709-2718. [CrossRef]

6. REN21. Renewables 2018 Global Status Report; REN21: Paris, France, 2018.

7. Nengroo, S.; Kamran, M.; Ali, M.; Kim, D.-H.; Kim, M.-S.; Hussain, A.; Kim, H.; Nengroo, S.H.; Kamran, M.A.; Ali, M.U.; et al. Dual Battery Storage System: An Optimized Strategy for the Utilization of Renewable Photovoltaic Energy in the United Kingdom. Electronics 2018, 7, 177. [CrossRef]

8. Turner, J.A. A realizable renewable energy future. Science 1999, 285, 687-689. [CrossRef]

9. Lin, A.; Lu, M.; Sun, P.; Lin, A.; Lu, M.; Sun, P. The Influence of Local Environmental, Economic and Social Variables on the Spatial Distribution of Photovoltaic Applications across China's Urban Areas. Energies 2018, 11, 1986. [CrossRef]

10. Liu, Z.; Wu, D.; Yu, H.; Ma, W.; Jin, G. Field measurement and numerical simulation of combined solar heating operation modes for domestic buildings based on the Qinghai-Tibetan plateau case. Energy Build. 2018, 167, 312-321. [CrossRef] 
11. Alsafasfeh, M.; Abdel-Qader, I.; Bazuin, B.; Alsafasfeh, Q.; Su, W.; Alsafasfeh, M.; Abdel-Qader, I.; Bazuin, B.; Alsafasfeh, Q.; Su, W. Unsupervised Fault Detection and Analysis for Large Photovoltaic Systems Using Drones and Machine Vision. Energies 2018, 11, 2252. [CrossRef]

12. Hosenuzzaman, M.; Rahim, N.A.; Selvaraj, J.; Hasanuzzaman, M.; Malek, A.B.M.A.; Nahar, A. Global prospects, progress, policies, and environmental impact of solar photovoltaic power generation. Renew. Sustain. Energy Rev. 2015, 41, 284-297. [CrossRef]

13. Roth, W. General concepts of photovoltaic power supply systems. Fraunhofer Inst. Sol. Energy Syst. ISE 2005, G07, 1-23.

14. Kumar Sahu, B. A study on global solar PV energy developments and policies with special focus on the top ten solar PV power producing countries. Renew. Sustain. Energy Rev. 2015, 43, 621-634. [CrossRef]

15. Zsiborács, H.; Pályi, B.; Pintér, G.; Popp, J.; Balogh, P.; Gabnai, Z.; Pető, K.; Farkas, I.; Baranyai, N.H.; Bai, A. Technical-economic study of cooled crystalline solar modules. Sol. Energy 2016, 140, 227-235. [CrossRef]

16. Enjavi-Arsanjani, M.; Hirbodi, K.; Yaghoubi, M. Solar Energy Potential and Performance Assessment of CSP Plants in Different Areas of Iran. Energy Procedia 2015, 69, 2039-2048. [CrossRef]

17. Statista, I. Cumulative Solar Photovoltaic Capacity Globally as of 2017, by Select Country (In Gigawatts). Available online: https://www.statista.com/statistics/264629/existing-solar-pv-capacity-worldwide/ (accessed on 12 September 2018).

18. Renewable Energy Policy Network for the 21st Century. Renewables 2019 Global Status Report; REN21: Paris, France, 2019.

19. Vokas, G.A.; Zoridis, G.C.; Lagogiannis, K.V. Single and Dual Axis PV Energy Production Over Greece: Comparison Between Measured and Predicted Data. Energy Procedia 2015, 74, 1490-1498. [CrossRef]

20. Green, M.A.; Dunlop, E.D.; Levi, D.H.; Hohl-Ebinger, J.; Yoshita, M.; Ho-Baillie, A.W.Y. Solar cell efficiency tables (version 54). Prog. Photovolt. 2019, 27. [CrossRef]

21. Bai, A.; Popp, J.; Balogh, P.; Gabnai, Z.; Pályi, B.; Farkas, I.; Pintér, G.; Zsiborács, H. Technical and economic effects of cooling of monocrystalline photovoltaic modules under Hungarian conditions. Renew. Sustain. Energy Rev. 2016, 60, 1086-1099. [CrossRef]

22. Eke, R.; Senturk, A. Performance comparison of a double-axis sun tracking versus fixed PV system. Sol. Energy 2012, 86, 2665-2672. [CrossRef]

23. Nsengiyumva, W.; Chen, S.G.; Hu, L.; Chen, X. Recent advancements and challenges in Solar Tracking Systems (STS): A review. Renew. Sustain. Energy Rev. 2018, 81, 250-279. [CrossRef]

24. Skouri, S.; Ben Haj Ali, A.; Bouadila, S.; Ben Salah, M.; Ben Nasrallah, S. Design and construction of sun tracking systems for solar parabolic concentrator displacement. Renew. Sustain. Energy Rev. 2016, 60, 1419-1429. [CrossRef]

25. Koussa, M.; Cheknane, A.; Hadji, S.; Haddadi, M.; Noureddine, S. Measured and modelled improvement in solar energy yield from flat plate photovoltaic systems utilizing different tracking systems and under a range of environmental conditions. Appl. Energy 2011, 88, 1756-1771. [CrossRef]

26. Koyuncu, B.; Balasubramanian, K. A microprocessor controlled automatic sun tracker. IEEE Trans. Consum. Electron. 1991, 37, 913-917. [CrossRef]

27. Kassem, A.; Hamad, M. A microcontroller-based multi-function solar tracking system. In 2011 IEEE International Systems Conference; IEEE: Montreal, QC, Canada, 2011; pp. 13-16.

28. Sallaberry, F.; Pujol-Nadal, R.; Larcher, M.; Rittmann-Frank, M.H. Direct tracking error characterization on a single-axis solar tracker. Energy Convers. Manag. 2015, 105, 1281-1290. [CrossRef]

29. Li, Z.; Liu, X.; Tang, R. Optical performance of vertical single-axis tracked solar panels. Renew. Energy 2011, 36, 64-68. [CrossRef]

30. Li, Z.; Liu, X.; Tang, R. Optical performance of inclined south-north single-axis tracked solar panels. Energy 2010, 35, 2511-2516. [CrossRef]

31. Chang, T.P. Performance study on the east-west oriented single-axis tracked panel. Energy 2009, 34, 1530-1538. [CrossRef]

32. Chang, T.P. The gain of single-axis tracked panel according to extraterrestrial radiation. Appl. Energy 2009, 86, 1074-1079. [CrossRef]

33. Sun, J.; Wang, R.; Hong, H.; Liu, Q. An optimized tracking strategy for small-scale double-axis parabolic trough collector. Appl. Therm. Eng. 2017, 112, 1408-1420. [CrossRef] 
34. Arbab, H.; Jazi, B.; Rezagholizadeh, M. A computer tracking system of solar dish with two-axis degree freedoms based on picture processing of bar shadow. Renew. Energy 2009, 34, 1114-1118. [CrossRef]

35. Song, J.; Yang, Y.; Zhu, Y.; Jin, Z. A high precision tracking system based on a hybrid strategy designed for concentrated sunlight transmission via fibers. Renew. Energy 2013, 57, 12-19. [CrossRef]

36. Chong, K.-K.; Wong, C.-W. General Formula for On-Axis Sun-Tracking System. In Solar Collectors and Panels, Theory and Applications; InTech: Rijeka, Croatia; Shanghai, China, 2010.

37. Lazaroiu, G.C.; Longo, M.; Roscia, M.; Pagano, M. Comparative analysis of fixed and sun tracking low power PV systems considering energy consumption. Energy Convers. Manag. 2015, 92, 143-148. [CrossRef]

38. Dakkak, M.; Babelli, A. Design and Performance Study of a PV Tracking System (100W-24Vdc/220Vac). Energy Procedia 2012, 19, 91-95. [CrossRef]

39. Chang, T.P. Output energy of a photovoltaic module mounted on a single-axis tracking system. Appl. Energy 2009, 86, 2071-2078. [CrossRef]

40. Huang, B.J.; Sun, F.S. Feasibility study of one axis three positions tracking solar PV with low concentration ratio reflector. Energy Convers. Manag. 2007, 48, 1273-1280. [CrossRef]

41. Alexandru, C.; Irina Tatu, N. Optimal design of the solar tracker used for a photovoltaic string. J. Renew. Sustain. Energy 2013, 5, 023133. [CrossRef]

42. Huang, B.J.; Ding, W.L.; Huang, Y.C. Long-term field test of solar PV power generation using one-axis 3-position sun tracker. Sol. Energy 2011, 85, 1935-1944. [CrossRef]

43. Yakup, M.A. bin H.M.; Malik, A. Optimum tilt angle and orientation for solar collector in Brunei Darussalam. Renew. Energy 2001, 24, 223-234. [CrossRef]

44. Lee, C.-Y.; Chou, P.-C.; Chiang, C.-M.; Lin, C.-F. Sun Tracking Systems: A Review. Sensors 2009, 9, 3875-3890. [CrossRef]

45. DEGERenergie GmbH \& Co. KG MLD SENSOR. Available online: http://www.degerenergie.de/en/mldsensor.html (accessed on 12 September 2018).

46. Amazon.com Inc. ECO-WORTHY Dual Axis Solar Tracking System. Available online: https://www.amazon. com/ECO-WORTHY-Dual-Solar-Tracking-System/dp/B00JYAIS9W (accessed on 12 September 2018).

47. Yilmaz, S.; Riza Ozcalik, H.; Dogmus, O.; Dincer, F.; Akgol, O.; Karaaslan, M. Design of two axes sun tracking controller with analytically solar radiation calculations. Renew. Sustain. Energy Rev. 2015, 43, 997-1005. [CrossRef]

48. Háber, I.; Kistelegdi, I.; Bötkös, T.; Farkas, I. Modeling solar irradiation data for photovoltaic energy-yield prediction. Pollack Period. 2013, 8, 27-34. [CrossRef]

49. Vickery, K.; Baron, R.J. Solar photovoltaic energy production comparison of east, west, south-facing and tracked arrays. Can. Soc. Bioeng. 2015, CSBE15070,1-10.

50. De Simón-Martín, M.; Alonso-Tristán, C.; Díez-Mediavilla, M. Performance Indicators for Sun-Tracking Systems: A Case Study in Spain. Energy Power Eng. 2014, 6, 292-302. [CrossRef]

51. Fraunhofer Institute for Solar Energy Systems. Photovoltaics Report; Fraunhofer ISE: Freiburg, Germany, 2018.

52. Szúcs, I. Applied Statistics; Agroinform Publishing Office: Budapest, Hungary, 2002.

(C) 2019 by the authors. Licensee MDPI, Basel, Switzerland. This article is an open access article distributed under the terms and conditions of the Creative Commons Attribution (CC BY) license (http://creativecommons.org/licenses/by/4.0/). 